\title{
A Content-based English Listening and Speaking Class for Hospitality Purposes
}

\author{
Shao-Wen $\mathrm{Su}$ \\ Department of Applied English, National Chin-Yi University of Technology, Taiwan \\ Email: shaowen@ncut.edu.tw
}

\begin{abstract}
This article demonstrates an ESP lesson plan to teach English listening and speaking for 49 EFL college students in hospitality fields, i.e. Western Culinary Arts and Bakery Technology and Management in Taiwan. This ESP class is content-based, featuring a combination of language-oriented, skills-oriented and learning-oriented approaches to ESP syllabus design. The syllabus aims at reaching satisfactory outcomes corresponding with preordained objectives. A variety of teaching and learning activities are applied within the framework of the Whole English Approach, such as lectures in an English-medium fashion, grammar understanding and practice, audio-lingual teaching activities as well as cooperative group and pair works. Cooperative team works function to enhance learning effects and motivation. Students' performance on two oral presentations illustrate itself as learner-centered output productions in the teaching and learning process, which adds to their learning outcomes in terms of communicative performance in a behavioral fashion. This lesson plan provides an example for EFL teachers who are interested or put endeavors in teaching ESP, especially for hospitality purposes.
\end{abstract}

Index Terms - content-based, ESP, hospitality fields, syllabus design

\section{INTRODUCTION}

This article demonstrates an ESP lesson plan to teach English listening and speaking for 49 EFL senior college students in hospitality disciplines, 28 from Western Culinary Arts and 21 from Bakery Technology and Management in Taiwan. The ESP class is content-based, featuring a combination of language-oriented, skills-oriented and learning-oriented approaches (Hutchinson \& Waters, 1993) to ESP syllabus design. A variety of teaching and learning activities are engaged in a Whole English Approach, such as lectures in an English-medium fashion, grammar understanding and practice, audio-lingual teaching activities.

Students are motivated to role-play the conversations in groups and in pairs. Cooperative learning is encouraged along with team spirit of negotiation and sharing. Adopting common-core teaching material complemented by related information on the Internet, the syllabus aims at reaching satisfactory outcomes corresponding with preordained teaching objectives/learning competencies.

\section{COURSE DESIGN}

\section{A. Rationale}

This is a 1-semester course. The course lasts for 18 weeks including 16 meeting weeks with 2 hours each and two weeks for mid-term and final exams. The course is designed as a content-based syllabus (Flowerdew, 1993; Kasper, 1995) with a rationale to meet both communicative and linguistic needs of the students. Given that the course encouraged students' performance in demonstrating their English listening and speaking skills applicable to their professional areas as well as valued interaction-cooperative learning process inside and outside the classroom (Breen, 1984), the course, thus, features a synthesis of, or otherwise a flexibly adapted combination of, language-oriented, skills-oriented and leaning-oriented approaches to the design of this ESP course. Elevating students' motivation is valued on the ground that motivation is one of the vital elements in bringing about the success of a language learning experience and in the development of ESP courses (Hutchinson \& Waters, 1993).

\section{B. Teaching Objectives}

- to enable students to understand the content learned and to apply it in the real-life context.

- to build up students' listening and speaking skills in a communicative fashion.

- to engage students in role-play activities.

- to develop students' abilities/skills of understanding and answering oral questions posed by the instructor.

- to cultivate students' speaking skills to express their own ideas and opinions in relationship to the content areas in English.

- to engage students in group/pair works.

- to engage students in the cooperative learning process of negotiation, organization and sharing inside and outside 
the classroom.

- to encourage students to independently search for and organize related information.

- to require students to demonstrate their performance/achievement in communicating in English with potential customers in simulated hospitality industry situations.

- to elevate students' learning motivation in a cooperative learning fashion in class.

\section{Targeted Learning Competencies}

- Understanding the ESP registers and discourse: the capacity to understand, remember and use the registers and discourse in hospitality industry in English. (language-oriented)

- Communicating ideas and information: the capacity to communicate with others using spoken and non-verbal expressions in the target language. (skills-oriented)

- Working in pairs and groups: the capacity to work as a member of a group to achieve a shared goal and complete a task. (learning-oriented)

- Solving problems: the capacity to achieve a solution for assignments or questions posed by the teachers by means of verbal performance in the target language. (skills-oriented, learning-oriented)

- Collecting, analyzing and organizing information: the capacity to find, sift and sort information and to present it in a useful way. (skills-oriented and learning-oriented)

- Elevating learning motivation: the capacity to enhance learning motivation and lower affective filter in the cooperative learning process. (learning-oriented)

\section{TEACHING CONTENT}

The EFL textbook, Ready to Order (Baude, Iglesias, \& Inesta, 2002), along with its workbook is adopted as common-core teaching material for the students majoring in the food/beverage preparation and catering industries. To carter for learning needs of the students with diverse English competencies and specialty disciplines, pieces of information from the following websites related to hospitality industry are used to supplement the teaching materials as follows.

1. Ready to Order and its workbook

2. Information available on the websites is referred to and covered in class:

(1) A website shows a wide variety of drink recipes at http://www.webtender.com.

(2) A website shows rules to prepare a French table, such as how to place guests, tableware displays, table decoration, assorted wines, and French recipes at http://www.ffcook.com/pages/table.htm.

(3) A website displays French tools and table at http://www.ffcook.com/pages/cooking.htm.

(4) A website shows how to mix whiskey cocktails at http://www.ehow.com/how_4583490_mix-whiskey-cocktails.html.

(5) A web page shows how to make a Mojito Cocktail: Cocktail Recipe

http://www.ehow.com/how_4478962_mojito-cocktail-cocktail-recipe.html\#ixzz18wyFjmz8.

(6) A website with wonderful videos to show people how to cook dishes at http://www.yumsugar.com/Name-Dish-3536759.

(7) A website provides videos to show how to cook Farfalle with lamb Ragu, Ricotta, and mint at http://www.myrecipes.com/recipes/dinnertonight/video/0,29865,1966502,00.html?utm_source=feedburner\&utm_mediu $\mathrm{m}=$ feed\&utm_campaign=Feed\%3A+DinnerTonight+\%28MyRecipes.com\%3A+Dinner+Tonight $\% 29$.

(8) A website shows utensils at http://www.amazon.com/tag/utensils.

(9) A website has wonderful videos to show how to cook desserts at http://www.5min.com/Category/Food/Desserts.

(10) A website shows dessert recipes at http://allrecipes.com/Recipes/Desserts/Main.aspx.

\section{TEACHING APPROACH}

A variety of teaching and learning activities within the framework of the Whole English Approach, such as lectures in an English-medium fashion, grammar understanding and practice, audio-lingual teaching activities as well as cooperative group and pair works is applied to the class. Both audio and video material/CDs are adopted to familiarize students with real-life English conversations at a natural speed.

Students are required to do pre-reading activities, discussion and exercise in class. Homework/tasks is assigned and functioned as a learning-centered increment in the learning process. Worksheets drawn from the workbook are assigned as homework for the students in order to re-enforce their acquisition and understanding of functional and grammatical structures as well as useful words and expressions for professionals in the hospitality industry. Students are motivated to role-play the conversations in groups and in pairs. Cooperative learning is thus encouraged along with team spirit of negotiation and sharing (Chen, 1994). Fun communicative games (e.g. Bingo, Matching, Association, Memory Test, Information Gap) are designed for the whole class to participate from time to time where necessary and appropriate.

\section{Assignments}

- Pre-reading assignments. 
- Homework is assigned: Worksheets drawn from the workbook.

- Tasks/projects are assigned for students' presentation.

TABLE 1

SCHEDULE

\begin{tabular}{|c|c|c|}
\hline \multirow{6}{*}{ Week 1} & \multicolumn{2}{|c|}{$\begin{array}{r}\text { SCHEDULE } \\
\end{array}$} \\
\hline & \multicolumn{2}{|c|}{ Introduction to the syllabus, Unit 1 Hello! } \\
\hline & Function: & (1) "break the ice": Introducing yourself. \\
\hline & Language: & (1) Asking for and giving personal information. \\
\hline & Vocabulary: & $\begin{array}{l}\text { (1) Greetings and introductions. } \\
\text { (2) Countries and nationalities. } \\
\text { (3) Pronunciation: word stress. }\end{array}$ \\
\hline & Activities: & $\begin{array}{l}\text { (1) Role-play. } \\
\text { (2) Lectures. } \\
\text { (3) Grammar understanding and practice. } \\
\text { (4) Discussion. } \\
\text { (5) Grouping. }\end{array}$ \\
\hline \multirow[t]{5}{*}{ Week 2} & \multicolumn{2}{|c|}{ Unit 2 A new job } \\
\hline & Function: & $\begin{array}{l}\text { (1) Describing a restaurant. } \\
\text { (2) Describing a kitchen. }\end{array}$ \\
\hline & Language: & $\begin{array}{l}\text { (1) The present simple (There is/There are). } \\
\text { (2) Prepositions of place. }\end{array}$ \\
\hline & Vocabulary: & $\begin{array}{l}\text { (1) The restaurant. } \\
\text { (2) The workplace. } \\
\text { (3) Jobs. } \\
\text { (4) Pronunciation: sentence stress. }\end{array}$ \\
\hline & Activities: & $\begin{array}{l}\text { (1) Role-play. } \\
\text { (2) Lectures. } \\
\text { (3) Grammar understanding and practice. } \\
\text { (4) Discussion and exercise in class. }\end{array}$ \\
\hline \multirow[t]{5}{*}{ Week 3} & \multicolumn{2}{|c|}{ Unit 3 The Casablanca } \\
\hline & Function: & $\begin{array}{l}\text { (1) Dealing with enquires. } \\
\text { (2) Giving directions. }\end{array}$ \\
\hline & Language: & $\begin{array}{l}\text { (1) Present continuous. } \\
\text { (2) Giving directions. }\end{array}$ \\
\hline & Vocabulary: & $\begin{array}{l}\text { (1) Verbs of movement. } \\
\text { (2) Pronunciation: questions. }\end{array}$ \\
\hline & Activities: & $\begin{array}{l}\text { (1) Role-play. } \\
\text { (2) Lectures. } \\
\text { (3) Games (Association, Memory Test) } \\
\text { (4) Grammar understanding and practice. } \\
\text { (5) Discussion in class. }\end{array}$ \\
\hline \multirow[t]{5}{*}{ Week 4} & \multicolumn{2}{|c|}{ Unit 3 The Casablanca } \\
\hline & Function: & (1) Giving directions. \\
\hline & Language: & (1) Prepositions of movement. \\
\hline & Vocabulary: & $\begin{array}{l}\text { (1) Seating arrangements. } \\
\text { (2) Table setting (http://www.ffcook.com/pages/table.htm) }\end{array}$ \\
\hline & Activities: & $\begin{array}{l}\text { (1) Role-play. } \\
\text { (2) Lectures. } \\
\text { (3) Games (Association, Memory Test) } \\
\text { (4) Discussion in class. }\end{array}$ \\
\hline \multirow[t]{5}{*}{ Week 5} & \multicolumn{2}{|c|}{ Unit 4 Reservation } \\
\hline & Function: & $\begin{array}{l}\text { (1) Taking reservations. } \\
\text { (2) Giving information about a restaurant. }\end{array}$ \\
\hline & Language: & $\begin{array}{l}\text { (1) Making bookings. } \\
\text { (2) Prepositions of time. }\end{array}$ \\
\hline & Vocabulary: & $\begin{array}{l}\text { (1) Clock times. } \\
\text { (2) Days, months and seasons. }\end{array}$ \\
\hline & Activities: & $\begin{array}{l}\text { (1) Role-play. } \\
\text { (2) Lectures. } \\
\text { (3) Discussion and practice in class. }\end{array}$ \\
\hline \multirow[t]{5}{*}{ Week 6} & \multicolumn{2}{|c|}{ Unit 5 Welcome! } \\
\hline & Function: & $\begin{array}{l}\text { (1) Receiving guests. } \\
\text { (2) Making arrangements. }\end{array}$ \\
\hline & Language: & (1) Modal verbs Going to + verb. \\
\hline & Vocabulary: & $\begin{array}{l}\text { (1) Parts of the dining-room. } \\
\text { (2) Tableware for breakfast, lunch, and dinner. } \\
\text { (3) Tableware display. (http://www.ffcook.com/pages/tware-p.htm) } \\
\text { (4) How to place your guests. (http://www.ffcook.com/pages/tplace-p.htm) }\end{array}$ \\
\hline & Activities: & $\begin{array}{l}\text { (1) Role-play (How to place your guests). } \\
\text { (2) Lectures. } \\
\text { (3) Grammar understanding and practice. } \\
\text { (4) Games (Bingo, Matching the right tableware). }\end{array}$ \\
\hline Week 7 & \multicolumn{2}{|r|}{ (4) Uants (Diा" } \\
\hline
\end{tabular}




\begin{tabular}{|c|c|c|}
\hline & Function: & $\begin{array}{l}\text { (1) Describing drinks. } \\
\text { (2) Ordering drinks. }\end{array}$ \\
\hline & Language: & $\begin{array}{l}\text { (1) Countable and uncountable nouns. } \\
\text { (2) Making requests. }\end{array}$ \\
\hline & Vocabulary: & $\begin{array}{l}\text { (1) Describing drinks. (http://www.webtender.com) } \\
\text { (2) Behind the bar. } \\
\text { (3) Tableware for drinks. } \\
\text { (4) Bar tools and supplies (http://webtender.barstore.com/) }\end{array}$ \\
\hline & Activities: & $\begin{array}{l}\text { (1) Role-play. } \\
\text { (2) Games (Memory test, Association). } \\
\text { (3) Lectures. } \\
\text { (4) Grammar understanding and practice. } \\
\text { (5) Discussion in class. }\end{array}$ \\
\hline Week 8 & \multicolumn{2}{|c|}{ Oral presentation in groups } \\
\hline Week 9 & \multicolumn{2}{|c|}{ Mid-term (written test) } \\
\hline \multirow[t]{5}{*}{ Week 10} & \multicolumn{2}{|c|}{ Unit 7 Cocktails } \\
\hline & Function: & (1) Cocktails recipes. \\
\hline & Language: & (1) Imperatives. \\
\hline & Vocabulary: & (1) Cocktail recipes. http://www.ehow.com/how_4583490_mix-whiskey-cocktails.html) \\
\hline & Activities: & $\begin{array}{l}\text { (1) Role-play. } \\
\text { (2) Games (Association, Bingo). } \\
\text { (3) Lectures. } \\
\text { (4) Grammar understanding and practice. }\end{array}$ \\
\hline \multirow[t]{5}{*}{ Week 11} & \multicolumn{2}{|c|}{ Unit 7 Cocktails } \\
\hline & Function: & (1) How to make cocktails. \\
\hline & Language: & (1) Linking words. \\
\hline & Vocabulary: & $\begin{array}{l}\text { (1) Cocktail recipes. } \\
\text { (http://www.ehow.com/how_4478962_mojito-cocktail-cocktail-recipe.html) } \\
\text { (2) Cocktail preparation. }\end{array}$ \\
\hline & Activities: & $\begin{array}{l}\text { (1) Role-play. } \\
\text { (2) Games (Association, Memory Test). } \\
\text { (4) Discussion in class. }\end{array}$ \\
\hline \multirow[t]{5}{*}{ Week 12} & \multicolumn{2}{|r|}{ (4) Discussioniliticlass. } \\
\hline & Function: & (1) Planning menus. \\
\hline & Language: & (1) Comparatives and superlatives. \\
\hline & Vocabulary: & $\begin{array}{l}\text { (1) Describing restaurants. } \\
\text { (2) Verbs of preparation. }\end{array}$ \\
\hline & Activities: & $\begin{array}{l}\text { (1) Games (Memory test, Information Gap). } \\
\text { (2) Lectures. } \\
\text { (3) Grammar understanding and practice. } \\
\text { (4) Discussion in class. }\end{array}$ \\
\hline \multirow[t]{5}{*}{ Week 13} & \multicolumn{2}{|r|}{ (4) Discussion ilit ciass. } \\
\hline & Function: & (1) Describing dishes. \\
\hline & Language: & (1) Verbs as adjectives. \\
\hline & Vocabulary: & (1) Ingredients. (http://www.yumsugar.com/Name-Dish-3536759) \\
\hline & Activities: & $\begin{array}{l}\text { (1) Role-play. } \\
\text { (2) Games (Association, Information Gap). } \\
\text { (3) Lectures. } \\
\text { (4) Discussion in class. }\end{array}$ \\
\hline \multirow[t]{5}{*}{ Week 14} & \multicolumn{2}{|c|}{ Unit 9 Here's the menu } \\
\hline & Function: & (1) Taking orders. \\
\hline & Language: & (1) Taking orders. \\
\hline & Vocabulary: & $\begin{array}{l}\text { (1) Describing dishes. } \\
\text { (2) Describing dishes. (http://www.yumsugar.com/Name-Dish-3536759) }\end{array}$ \\
\hline & Activities: & $\begin{array}{l}\text { (1) Lectures. } \\
\text { (2) Discussion and practice in class. }\end{array}$ \\
\hline \multirow[t]{5}{*}{ Week 15} & \multicolumn{2}{|c|}{ Unit 10 The chef recommends } \\
\hline & Function: & (1) Recommending dishes. \\
\hline & Language: & $\begin{array}{l}\text { (1) Past tense (irregular verbs). } \\
\text { (2) Recommending dishes. } \\
\text { (http://www.yumsugar.com/Name-Dish-3536759) }\end{array}$ \\
\hline & Vocabulary: & Verbs of preparation. \\
\hline & Activities: & $\begin{array}{l}\text { (1) Role-play. } \\
\text { (2) Lectures. } \\
\text { (3) Games (Association, Memory test) } \\
\text { (4) Discussion and practice in class. }\end{array}$ \\
\hline \multirow[t]{4}{*}{ Week 16} & & Unit 10 The chef recommends \\
\hline & Function: & (1) Describing desserts \\
\hline & Language: & (1) Past tense (irregular verbs). \\
\hline & Vocabulary: & $\begin{array}{l}\text { (1) Desserts. } \\
\text { (http://www.5min.com/Category/Food/Desserts) } \\
\text { (http://allrecipes.com/Recipes/Desserts/Main.aspx) }\end{array}$ \\
\hline
\end{tabular}




\begin{tabular}{l|l|l|}
\hline & & (2) Utensils. (http://www.amazon.com/tag/utensils) \\
\cline { 2 - 3 } & Activities: & $\begin{array}{l}\text { (1) Lectures. } \\
\text { (2) Games (Bingo, Information Gap) } \\
\text { (3) Discussion and practice in class. }\end{array}$ \\
\hline Week 17 & \multicolumn{2}{|c|}{ Project-oral presentation in groups } \\
\hline Week 18 & \multicolumn{2}{|l|}{ Final Exam (written test) } \\
\hline
\end{tabular}

\section{STUDENT ASSESSMENT SYSTEM}

Student assessment takes the forms of tests and oral presentations. Students are required to sit in two achievement tests in order to demonstrate their learning achievement and acquisition of profession-knowledge and expressions learned from this content-based syllabus. The two written tests are administered during and after the course serving as a criterion-referenced formative evaluation of students learning accomplishment. The tests take up a format consisting of four parts, namely, vocabulary (30\%), multiple choice (20\%), translation $(30 \%)$ and short questions $(20 \%)$. The translation part purports to test students' understanding of ESP linguistic registers, namely vocabulary, phrases and expressions in hospitality fields and to address students' learning objective: capacity to understand the content learned, which is the registers and discourse in hospitality industry in English. The parts of cloze-vocabulary and multiple choice together aim at testing students' understanding of the registers related to the target situation in context. The purpose of these sections is directed at testing students' learning achievement in terms of capacity to understand the content learned and to communicate with others the ideas and information relevant to their subject matters. This purpose reflects the testing rationale in accordance with pre-designed Learning Competencies one and two. The short questions focus on looking at students' application ability. Again, this section of the tests bears an aim at addressing the teaching objectives of understanding of the content learned and the application ability.

More importantly, students are required to demonstrate their English communicative abilities/skills using spoken and non-verbal expressions in English in a behavioral fashion, which are in reference to Targeted Learning Competencies two. Students are encouraged to present in English in a form of PowerPoint and/or live demonstration to explain and/or act out the target situations of cocktail making and cuisine preparation. The group practice is meant to lower students' affective filter and to encourage peer cooperation, and the learning competence of elevating students' learning motivation is targeted. The first oral presentation is performed in the halfway of the course while the second is undertaken near the end of the course. Two respective open-ended topics in relation to their subject-specific areas are assigned. For the first presentation, the students are required to research, in groups, for the origin and background information on recipes of cocktail-making, Chinese dishes, Western dishes, or pastry of their own preference and to present it in class. As for the second presentation, they are assigned to work on such a project as to simulate a chef, responsible for promoting one of the best/most famous dishes for their own restaurant. They are required to demonstrate how to cook or bake it in front of their potential customers.

The oral testing/presentation specification is provided only to set a framework or guideline for the students to follow with a lot of rooms left for students' decision-making as to exactly how and what they present themselves. In this fashion, the learning skills of communication, problem solving, cooperation as well as data collection, analysis and organization are derived to correspond to the pre-designed Learning Competencies from three to six.

\section{Scoring}

- Homework, class involvement and class attendance: $20 \%$.

- Achievement tests (Mid-term Exam and Final Exam): $40 \%$.

- Oral presentations: 40\%. (considered an output production and application of the acquired English competence to ESP knowledge and skills in the target situations)

\section{CONCLUSION}

This content-based class, characterized by a synthesis of language-oriented, skills-oriented and learning-oriented approaches to ESP syllabus design and conducted in Whole English Approach, might appear to be of intimidation to some of the students. Fun games help reduce the level of intimidation. Audio and video aids/supplementary materials provide authentic materials, so as to cater for divergent learning needs of the students and for those with a higher English proficiency level. Cooperative team works function to enhance learning effects and motivation. Students' performance on two oral presentations illustrate itself as learner-centered output productions in the teaching and learning process, which adds to their learning outcomes in terms of communicative performance in a behavioral fashion. This content-based ESP model functions as a point of departure for the design of relative courses.

\section{ACKNOWLEDGEMENT}

The author of this paper would like to extend gratitude to National Science Council in Taiwan for its research grants (NSC99-2410-H-167-002). Special appreciation also goes to Dr. Tim Newfields, an associate professor in Toyo University, Tokyo, Japan for his insightful feedback on this paper. 


\section{REFERENCES}

[1] Baude, A., Iglesias, M., \& Inesta, A. (2002). Ready to Order. England: Pearson Education Limited.

[2] Breen, M. P. (1984). Process Syllabuses for the Language Classroom. In C. J. Brumfit (ed.), General English Syllabus Design, ELT Document 118 (pp.47-60). Oxford: Pergamon Press in association with the British Council.

[3] Chen, H.-C. (1994). Team-teaching English for Specific Purposes: a New Perspective. The Proceedings of the $2^{\text {nd }}$ International Symposium on English Teaching (pp.79-96). Taipei, Taiwan: Crane.

[4] Flowerdew, J. (1993). Content-based Language Instruction in a Tertiary Setting. English for Specific Purposes, 12, $121-138$.

[5] Hutchinson, T., \& Waters, A. (1993). English for Specific Purpose: A Learning-centred Approach (8 ${ }^{\text {th }}$ ed). Cambridge: Cambridge University Press.

[6] Kasper, L. F. (1995). Theory and Practise in Content-based ESL Reading Instruction. English for Specific Purposes, 14, 223-230.

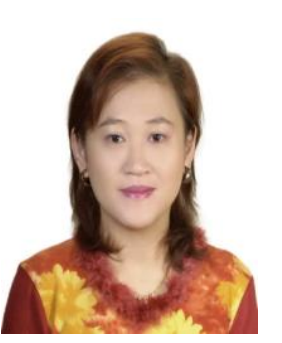

Shao-Wen Su was born in Tainan, Taiwan. She received her Doctor of Philosophy $(\mathrm{PhD})$ degree in Education from The University of Newcastle in Australia in 2003 as well as a MA in English Literature and Language (Taiwan) in 1990 and a BA in Foreign Literature and Languages (Taiwan) in 1987.

She currently teaches in Department of Applied English at National Chin-Yi University of Technology (Taiwan), holding a position of Associate Professor. She has been teaching EFL in colleges and universities for nearly 19 years.

Her research interests include areas of English writing, English literature and ESP instructions as well as curriculum design and evaluation. Currently, she has embarked on exploring issues of difficulties that teaching faculty in fields of humanities and social sciences encounter and ways to elevate their research capability. Her further study will focus on possible correlations between teaching efficiency and academic performance and between research belief/motivation and academic performance.

Her recent publications include: (1) Su, Shao-Wen (2010). English placement practice and instruction: A needs analysis from the perspective of technological university students. Journal of National Kaohsiung Normal University, 29. (2) Su, Shao-Wen (2010). Motivating and justifiable: Teaching Western literature to EFL students at a Taiwanese university of science and technology. TESL-EJ, 14(1). (3) Su, Shao-Wen (2009). A study of graduation threshold of English competency from the perspective of EFL teachers of technological institutions in Southern Taiwan. Journal of National Kaohsiung Normal University, 27. (4) Su, Shao-Wen (2009). Perceptions on elevating academic research capability: A study from the perspective of humanities and social science teachers in a private technological university. Chung Cheng Educational Studies, 8(2). (5) Su, Shao-Wen (2009). A reflection on the teaching of foreign language teachers. Journal of Cheng Shiu University, 22. (6) Su, Shao-Wen (2009). Arthur Miller's Death of a Salesman as a modern tragedy of a father. Studies in English Language and Literature, 23. (7) Su, Shao-Wen (2008). English teaching materials, methodology, and student assessment: A comparative study of the perceptions of junior college students and teachers. English Teaching and Learning, 32(1). (8) Su, Shao-Wen (2007). Absurdity and certitude: Waiting for Godot as the Theatre of the Absurd. Studies in English Language and Literature, 20. (9) Su, Shao-Wen (2006). Beyond the unconscious: "Gaze" in Peter Shaffer's Equus, Tamkang Review, 36(3). (10) Su, Shao-Wen (2005). Graduation threshold of English competency: A needs analysis from the perspective of technological institute students. Educational Review, 24.

Dr. Su is a member of ETRA (The English Teaching and Research Association) and ETA (English Teachers' Association) in Taiwan. 